4

5

Supplementary Information

6 


$\begin{array}{lr}\text { Supplementary Methods } & 3 \\ \text { Supplementary Tables } & 4 \\ \text { Supplementary References } & 17\end{array}$

\section{List of Tables}

Table S1: Assumptions and average $\mathrm{CO}_{2}$ emissions from vehicle manufacture (UK values shown).

Table S2: Baseline indicators for the study cities: modal split, population size, cycling network density, and mean ambient temperature.....

Table S3: Selection of relevant questions from the PASTA survey questionnaire.

Table S4: Derived mean $\mathrm{CO}_{2}$ emissions per passenger-km by city, emissions category and transport mode (2014-2017 average to match study period).

Table S5: Observed modal split (by trip or distance) and average daily distance travelled for each city at baseline and follow-up. Table S6: Results of the association between change in mobility-related lifecycle $\mathrm{CO}_{2}$ emissions $\left(\mathrm{kgCO}_{2} /\right.$ day) and change in transport mode usage (trips/day) $(\mathrm{n}=1849) \ldots$

Table S7: Results for the association between change in lifecycle $\mathrm{CO}_{2}$ emissions (kg/day) and change in main mode of travel $(n=1849)$

Table S8: Results for the association between change in $\mathrm{CO}_{2}$ emissions $\left(\mathrm{kgCO}_{2} /\right.$ day) and change in daily cycling trips $(\mathrm{n}=1849)$

Table S9: Results for the association between change in $\mathrm{CO}_{2}$ emissions $\left(\mathrm{kgCO}_{2} /\right.$ day) and change in cycling frequency categories $(n=1849)$.

Table S10: Results of the association between change in mobility-related lifecycle $\mathrm{CO}_{2}$ emissions and change in transport mode usage, by trip purpose $(n=1849)$. Table S11: Results of the association between change in mobility-related lifecycle $\mathrm{CO}_{2}$ emissions and change in main mode of transport, by trip purpose $(n=1849)$. Table S12: Results of the association between change in mobility-related lifecycle $\mathrm{CO}_{2}$ emissions and change in daily cycling trips by trip purpose $(n=1849)$. Table S13: Results of the association between change in mobility-related lifecycle $\mathrm{CO}_{2}$ emissions and change in cycling frequency categories by trip purpose $(n=1849)$. 


\section{Supplementary Methods}

\section{SM1 Carbon calculation methods}

Total operational emissions were derived as follows:

$$
E_{t}=\sum_{\text {mode }} e f_{\text {hot }, t}(\text { mode }, \text { speed }, \text { fuel,purpose }) * p k m_{t}(\text { mode })+E_{\text {cold }}(\text { temp }, \text { length })
$$

Where: $E_{t}=\mathrm{CO}_{2}$ emissions; $t=$ trip, ef hot, $($ mode $)=$ "hot" emissions factor for $\operatorname{mode}$ and trip $t ; p k m_{t}($ mode $)=$ trip distance for mode and trip $t, E_{\text {cold }}=$ "cold start" excess emissions (for cars only); temp=ambient temperature; length=trip length.

The first term includes speed-dependency of emissions factors (based on the European Environment Agency's COPERT 5 model (EEA, 2012)):

$$
e f_{\text {hot }}=\frac{a+c * V+e * V^{2}}{1+b * V+d * V^{2}}
$$

Where: $V=a v e r a g e ~ s p e e d ;$ coefficients $a$ to $e$ are empirically derived for gasoline and diesel fuels (EEA, 2012).

While "hot" emissions dominate total emissions, "cold start" emissions should not be neglected as they constitute a significant share of total emissions for shorter trip lengths (typically $15-20 \%$ ). $E_{\text {cold }}$ was derived for each vehicle technology $k$ as:

$$
\begin{aligned}
E_{\text {cold }, k}= & \beta_{k} * p k m_{k} * e f_{\text {hot }, k} *\left(\frac{e f_{\text {cold }, k}}{e f_{\text {hot }, k}}-1\right) \\
& \frac{e f_{\text {cold }, k}}{e f_{\text {hot }, k}}=l-m * \text { temp }
\end{aligned}
$$

Where: $\beta=$ fraction of mileage driven with a cold engine or the catalyst operated below the light-off temperature,$p k m_{k}=$ passenger-km, $e_{\text {cold }} / e_{\text {hot }}=$ cold $/$ hot emission quotient for vehicles of technology $k$, temp=ambient temperature. $I=1.47, m=0.009$ (gasoline); $I=1.34, m=0.008$ (diesel) based on (EEA, 2012).

The $\beta$ parameter depends upon ambient temperature and trip length (EEA, 2012). Vehicle fuel type shares (gasoline, diesel, electric, other) and average occupancy rates for each city were based on international databases (ACEA/ANFAC, 2014; Eurostat, 2016; IEA, 2015; IIASA, 2014; SMMT, 2014).

Energy supply emissions for e-bikes, cars, buses, urban rail were based on different values for 'Well-To-Tank' emissions of gasoline $\left(0.654 \mathrm{kgCO}_{2}\right.$ per $\mathrm{kg}$ of fuel), diesel $\left(0.688 \mathrm{kgCO}_{2}\right.$ per $\mathrm{kg}$ of fuel) and delivered electricity, with the latter varying significantly between countries (up to 3 orders of magnitude, reflecting the use of high shares of renewable sources vs. high shares of fossil fuels).

Vehicle production emissions factors on a per passenger-km basis are shown in Supplementary Tables

Table S1 for the UK. Note that in this paper we used country-specific factors to reflect local differences in occupancy rates and electricity generation mixes for the different motorized modes (EC DG Climate Action, 2013). 
Table S1: Assumptions and average $\mathrm{CO}_{2}$ emissions from vehicle manufacture (UK values shown)

\begin{tabular}{|c|c|c|c|c|}
\hline Mode & $\begin{array}{l}\text { Total vehicle weight } \\
\text { (tons) }\end{array}$ & $\begin{array}{l}\mathrm{CO}_{2} \text { per vehicle } \\
\text { ( } \mathrm{CO}_{2} / \mathrm{veh} \text {.) }\end{array}$ & $\begin{array}{l}\text { Lifetime mileage } \\
(\mathbf{k m})\end{array}$ & $\begin{array}{l}\mathrm{CO}_{2} \text { per pass-km } \\
\left(\mathrm{gCO}_{2} / \mathrm{pkm}\right)\end{array}$ \\
\hline Bicycle & 0.017 & 0.10 & 20,000 & 4.9 \\
\hline E-bike / pedelec $\$$ & 0.024 & 0.19 & 20,000 & 9.3 \\
\hline Motorcycles & 0.15 & 0.54 & 50,000 & 10.3 \\
\hline Average car & 1.295 & 4.7 & 150,000 & 20.0 \\
\hline Average bus & 11 & 39.5 & $1,000,000$ & 3.2 \\
\hline Urban rail & 66 & 237.1 & $1,500,000$ & 4.0 \\
\hline
\end{tabular}

\section{8}

Table S2: Baseline indicators for the study cities: modal split, population size, cycling network density, and mean ambient temperature

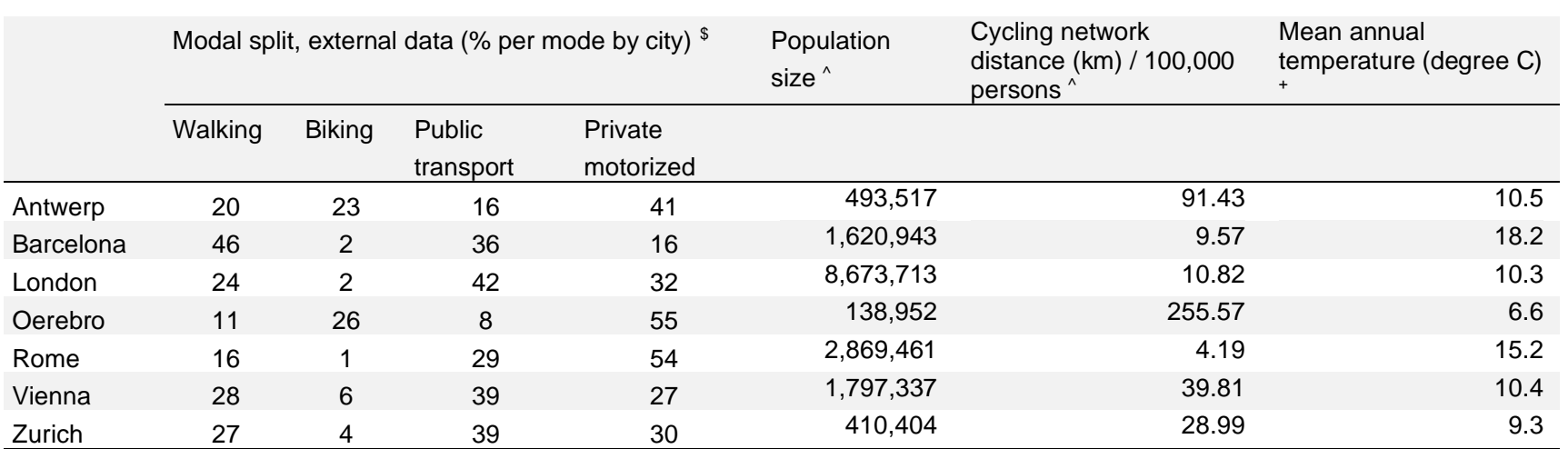

$\$$ Antwerp (2010). The EPOMM Modal Split Tool. (http://www.epomm.eu/tems/)

Barcelona (2012). (http://w110.bcn.cat/Mobilitat/Continguts/DB_2012_compr.pdf)

London (2011). PASTA project - City factsheet London.

Oerebro (2011). The EPOMM Modal Split Tool. (http://www.epomm.eu/tems/)

Rome (2013). Mobility data from city survey.

Vienna (2010). STEP 2025 (S. 106), Source Wr. Linien.

Zurich (2010). Mikrozensus Mobilität und Verkehr 2010. (Umweltbericht 2013 Stadt Zürich)

^Mueller, N.; Rojas-Rueda, D.; Salmon, M.; Martinez, D.; Ambros, A.; Brand, C.; de Nazelle, A.; Dons, E.; Gaupp-Berghausen, M.; Gerike, R.; Götschi, T.; lacorossi, F.; Int Panis, L.; Kahlmeier, S.; Raser, E.; Nieuwenhuijsen, M. Health impact assessment of cycling network expansions in European cities. Prev Med 2018; 109:62-70.

+ ‘List of European cities by temperature' - Wikipedia: https://en.wikipedia.org/wiki/List_of_European_cities_by_temperature 
107 Table S3: Selection of relevant questions from the PASTA survey questionnaire

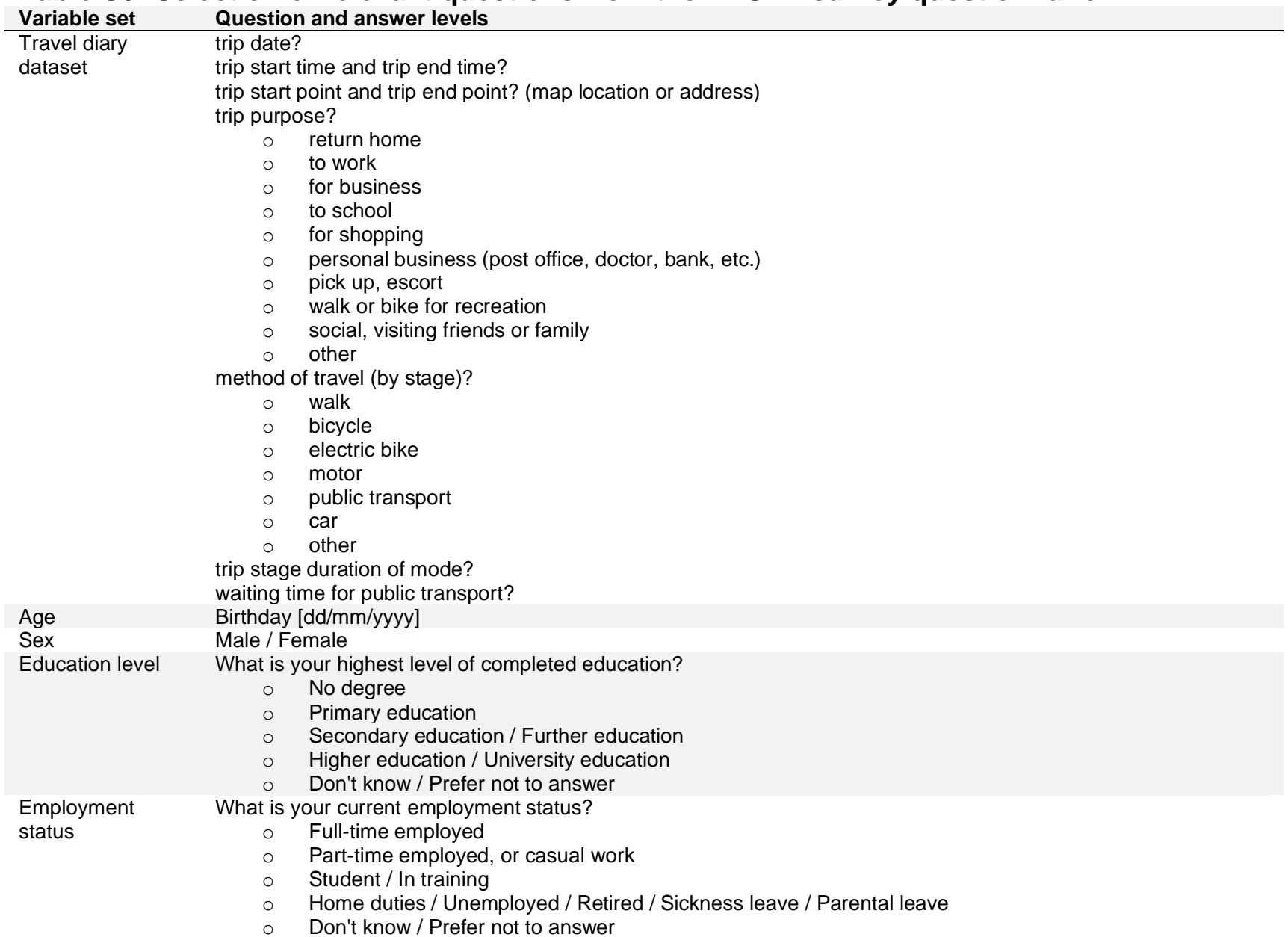

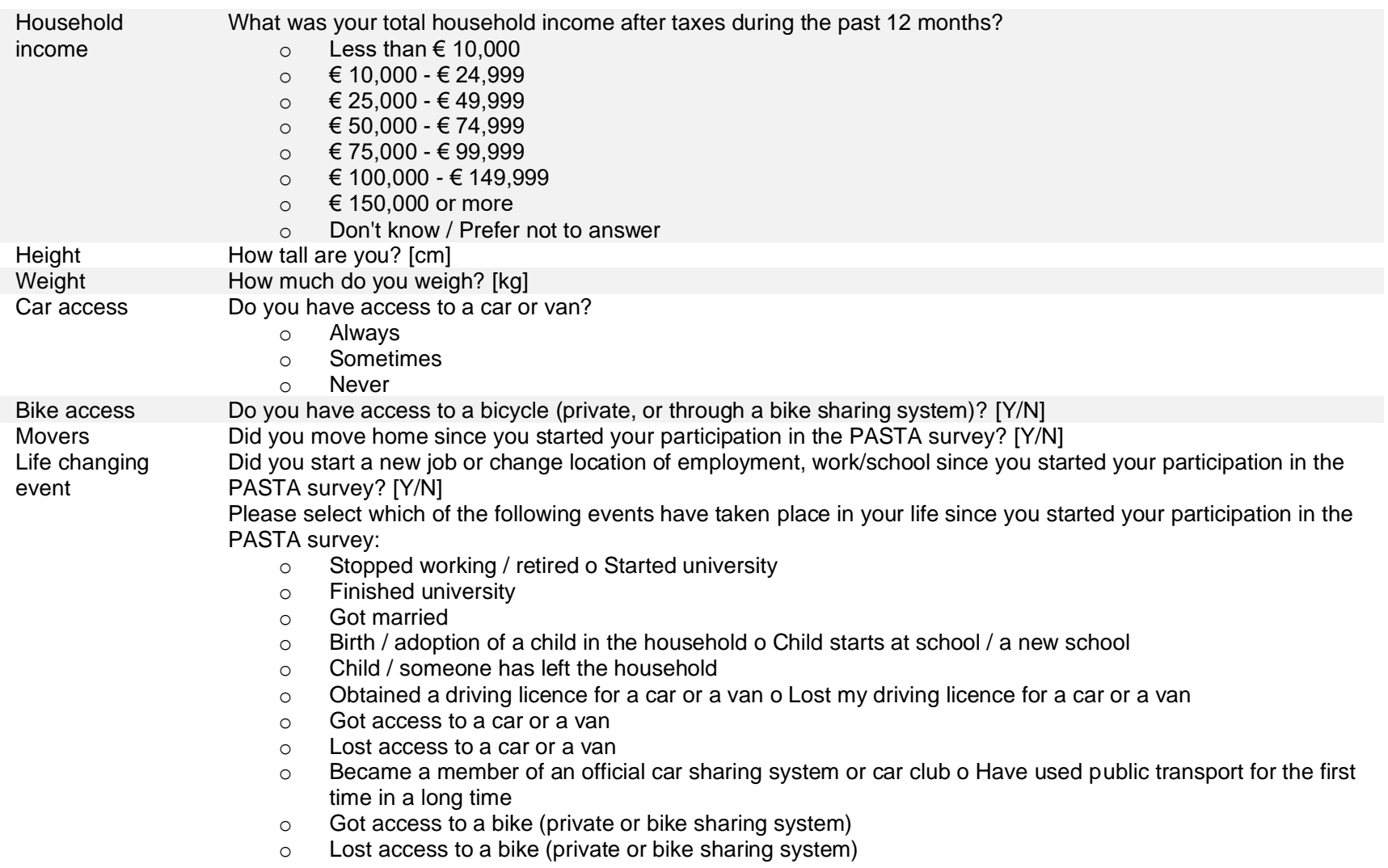


Started to ride an electric bike

Stopped to ride an electric bike

Cycling conditions have noticeably improved in my area

Cycling conditions have noticeable deteriorated in my area o Walking conditions have noticeably improved in my area

Walking conditions have noticeably deteriorated in my area 
Table S4: Derived mean $\mathrm{CO}_{2}$ emissions per passenger-km by city, emissions category and transport mode (2014-2017 average to match study period)

\begin{tabular}{|c|c|c|c|c|c|c|c|c|c|c|c|c|c|c|c|c|}
\hline \multirow[b]{3}{*}{ City } & \multicolumn{4}{|c|}{ Operational } & \multicolumn{6}{|c|}{ Energy/fuel supply } & \multicolumn{6}{|c|}{ Vehicle supply } \\
\hline & \multicolumn{2}{|c|}{$\begin{array}{l}\text { Car, van or } \\
\text { motorcycle }^{*} \\
\text { gCO } 2 / p k m\end{array}$} & \multicolumn{2}{|c|}{$\begin{array}{c}\text { Public } \\
\text { transport }^{+} \\
\text {gCO2/pkm }\end{array}$} & \multicolumn{2}{|c|}{$\begin{array}{c}\text { Car, van, } \\
\text { motorcycle * } \\
\text { gCO2/pkm }\end{array}$} & \multicolumn{2}{|c|}{$\begin{array}{l}\text { Public } \\
\text { transport }^{+} \\
\text {gCO2 } 2 / p k m^{+}\end{array}$} & \multicolumn{2}{|c|}{$\begin{array}{c}\text { Bicycle, e- } \\
\text { bike } \\
\text { gCO2/pkm }\end{array}$} & \multicolumn{2}{|c|}{$\begin{array}{c}\text { Car, van, } \\
\text { motorcycle * } \\
\text { gCO2/pkm }\end{array}$} & \multicolumn{2}{|c|}{$\begin{array}{c}\text { Public } \\
\text { transport }^{+} \\
\text {gCO2/pkm }\end{array}$} & \multicolumn{2}{|c|}{$\begin{array}{c}\text { Bicycle, e- } \\
\text { bike } \# \\
\text { gCO2/pkm }\end{array}$} \\
\hline & mean & SD & mean & SD & mean & SD & mean & SD & mean & SD & mean & SD & mean & SD & mean & SD \\
\hline Antwerp & 141.5 & 38.6 & 14.5 & 0.1 & 27.2 & 5.6 & 20.9 & 0.5 & 0.111 & 0.003 & 12.9 & 1.9 & 2.9 & 0.0 & 5.1 & 0.0 \\
\hline Barcelona & 142.2 & 45.8 & 17.2 & 0.1 & 27.5 & 7.2 & 30.5 & 0.6 & 0.171 & 0.004 & 10.6 & 1.6 & 3.0 & 0.0 & 5.1 & 0.0 \\
\hline London & 165.6 & 46.7 & 52.0 & 0.3 & 30.4 & 6.8 & 43.5 & 0.6 & 0.236 & 0.004 & 12.9 & 1.9 & 3.6 & 0.0 & 5.1 & 0.0 \\
\hline Oerebro & 153.3 & 46.8 & 68.8 & 0.3 & 27.5 & 6.1 & 16.7 & 0.1 & 0.011 & 0.000 & 13.2 & 2.1 & 4.2 & 0.0 & 5.1 & 0.0 \\
\hline Rome & 144.5 & 37.5 & 36.4 & 0.2 & 27.7 & 6.0 & 33.9 & 0.6 & 0.200 & 0.004 & 11.5 & 1.8 & 3.1 & 0.0 & 5.1 & 0.0 \\
\hline Vienna & 156.1 & 45.2 & 24.7 & 0.1 & 29.4 & 6.6 & 16.6 & 0.2 & 0.087 & 0.002 & 13.3 & 2.0 & 2.8 & 0.0 & 5.1 & 0.0 \\
\hline Zurich & 143.6 & 45.7 & 43.4 & 0.2 & 26.8 & 6.2 & 9.8 & 0.1 & 0.002 & 0.000 & 12.5 & 1.8 & 3.4 & 0.0 & 5.1 & 0.0 \\
\hline
\end{tabular}

* This incorporates different journey speeds, vehicle occupancy rates by trip purpose, national fuel shares of the vehicle fleet, and cold start emissions. A $22 \%$ uplift was applied to account for 'real world' driving conditions. For example in Antwerp in 2016, the car fleet was assumed to comprise the national fleet mix of $38 \%$ gasoline, $61 \%$ diesel and $1 \%$ electric; buses were $100 \%$ diesel; motorcycles $100 \%$ gasoline. Car occupancy rate was between 1.16 (commuting) and 2.02 (education), average 1.54 for all trip purposes. Cold/hot ratio of 1.3 and cold trip distance of $3.45 \mathrm{~km}$.

+ Operational emissions are for bus using average occupancy rates. Energy/fuel supply assume a bus/rail share based on EPOMM Modal Split Tool. (http://www.epomm.eu/tems/). For example, Antwerp bus/rail share was 37.5\% in 2016.

\# The observed e-bike share was 4.5\%; therefore, average emissions include $4.5 \%$ e-bike, $95.5 \%$ normal bike.

Sources: hot and cold emissions factor coefficients (EEA, 2012; EMEP/EEA, 2016); vehicle fleets (ACEA/ANFAC, 2014; DEFRA/DECC, 2016; DfT, 2015; SMMT, 2016).

Table S5: Observed modal split (by trip or distance) and average daily distance travelled for each city at baseline and follow-up

Modal split, observed data (by trip), percent

\begin{tabular}{|c|c|c|c|c|c|}
\hline & $\begin{array}{l}\text { Modal s] } \\
\text { Walking }\end{array}$ & $\begin{array}{r}\text { lit, obser } \\
\text { perc } \\
\text { Cycling }\end{array}$ & $\begin{array}{l}\text { ed data (b) } \\
\text { ent } \\
\text { Public } \\
\text { transport }\end{array}$ & $\begin{array}{l}\text { trip), } \\
\text { Car, } \\
\text { van } \\
\text { or } \\
\text { moto }\end{array}$ & Walki \\
\hline Antwerp & 10.3 & 58.0 & 6.9 & 24.8 & \\
\hline Barcelona & 36.9 & 17.6 & 29.2 & 16.3 & \\
\hline London & 29.4 & 30.9 & 33.4 & 6.4 & \\
\hline Orebro & 13.1 & 37.9 & 3.4 & 45.7 & \\
\hline Rome & 18.0 & 20.9 & 32.3 & 28.8 & \\
\hline Vienna & 23.8 & 24.8 & 36.8 & 14.6 & \\
\hline Zurich & 24.4 & 25.3 & 39.5 & 10.9 & \\
\hline All cities & 23.3 & 29.7 & 28.0 & 19.1 & \\
\hline
\end{tabular}

Modal split, observed data (by

\begin{tabular}{l|rrrr|} 
Antwerp & 8.1 & 54.7 & 7.3 & 29.9 \\
Barcelona & 36.9 & 15.5 & 28.0 & 19.6 \\
London & 29.0 & 29.0 & 34.5 & 7.5 \\
Orebro & 13.7 & 31.1 & 2.9 & 52.3 \\
Rome & 13.0 & 24.2 & 30.1 & 32.8 \\
Vienna & 21.5 & 28.8 & 35.3 & 14.4 \\
Zurich & 23.0 & 24.0 & 41.9 & 11.1 \\
All cities & $\mathbf{2 1 . 7}$ & $\mathbf{2 9 . 1}$ & $\mathbf{2 7 . 8}$ & $\mathbf{2 1 . 4}$ \\
\hline
\end{tabular}
distance), percent

Cycling Public transport van Car,
van
or moto

\section{Baseline (to)}

$\begin{array}{lll}0.7 & 31.9 & 24.5\end{array}$

$5.5 \quad 9.5$

$4.9 \quad 24.0$

$1.5 \quad 12.9$

$\begin{array}{ll}1.8 & 10.2\end{array}$

$2.4 \quad 14.2$

$2.1 \quad 9.7$

$2.5 \quad 15.4$

Follow-up ( $\left.t_{1}\right)$

Average distance travelled, $\mathbf{k m}$ per day

Walking Cycling Public Car, transport van or moto

\begin{tabular}{lrrr|rrrr} 
Follow-up $\left(\mathbf{t}_{\mathbf{1}}\right)$ & & & & & & \\
0.8 & 26.4 & 18.1 & 54.7 & 0.34 & 10.71 & 7.36 & 22.22 \\
5.9 & 8.1 & 42.2 & 43.9 & 1.58 & 2.16 & 11.26 & 11.72 \\
4.2 & 18.3 & 56.2 & 21.3 & 1.25 & 5.41 & 16.64 & 6.31 \\
1.1 & 8.4 & 12.2 & 78.3 & 0.39 & 2.92 & 4.26 & 27.34 \\
1.5 & 10.7 & 39.4 & 48.3 & 0.55 & 3.82 & 14.04 & 17.20 \\
2.5 & 12.9 & 51.4 & 33.2 & 0.84 & 4.41 & 17.62 & 11.39 \\
1.7 & 9.0 & 64.2 & 25.0 & 0.72 & 3.72 & 26.54 & 10.33 \\
$\mathbf{2 . 4}$ & $\mathbf{1 3 . 6}$ & $\mathbf{4 2 . 8}$ & $\mathbf{4 1 . 2}$ & $\mathbf{0 . 8 4}$ & $\mathbf{4 . 7 3}$ & $\mathbf{1 4 . 9 5}$ & $\mathbf{1 4 . 3 8}$ \\
\hline
\end{tabular}


120

121

\section{SI-8}


Table S6: Results of the association between change in mobility-related lifecycle $\mathrm{CO}_{2}$ emissions $\left(\mathrm{kgCO}_{2} /\right.$ day) and change in transport mode usage (trips/day) $(\mathrm{n}=1849)$

\begin{tabular}{|c|c|c|c|c|c|c|}
\hline & \multicolumn{2}{|l|}{ Model 0: unadjusted } & \multicolumn{2}{|l|}{ Model 1: partly adjusted } & \multicolumn{2}{|l|}{ Model 2: fully adjusted } \\
\hline & Coefficient $(95 \% \mathrm{Cl})$ & $\mathrm{p}$-value & Coefficient $(95 \% \mathrm{Cl})$ & $\mathrm{p}$-value & Coefficient $(95 \% \mathrm{Cl})$ & $\mathrm{p}$-value \\
\hline \multirow{2}{*}{\multicolumn{7}{|c|}{$\begin{array}{l}\text { Change in transport mode } \\
\text { usage (trips per day) }\end{array}$}} \\
\hline & & & & & & \\
\hline Bike & $-0.516(-0.818$ to -0.215$)$ & $<0.0001$ & $-0.524(-0.826$ to -0.222$)$ & 0.001 & $-0.517(-0.821$ to -0.214$)$ & 0.001 \\
\hline Car & 2.127 (1.808 to 2.445$)$ & $<0.0001$ & 2.117 (1.799 to 2.436$)$ & $<0.0001$ & 2.105 (1.783 to 2.427 ) & $<0.0001$ \\
\hline Public transport & 0.448 (0.121 to 0.776$)$ & 0.007 & 0.461 (0.134 to 0.789$)$ & 0.006 & 0.445 (0.114 to 0.776$)$ & 0.008 \\
\hline Walk & $-0.409(-0.691$ to -0.127$)$ & 0.005 & $-0.406(-0.688$ to -0.123$)$ & 0.005 & $-0.406(-0.691$ to -0.121$)$ & 0.005 \\
\hline \multicolumn{7}{|l|}{ Sex } \\
\hline Male & & & 0 & -- & 0 & -- \\
\hline Female & & & $0.019(-0.809$ to 0.847$)$ & 0.964 & $0.024(-0.821$ to 0.87$)$ & 0.955 \\
\hline Age at $t_{0}$ (years) & & & $-0.033(-0.074$ to 0.008$)$ & 0.115 & $-0.04(-0.083$ to 0.003$)$ & 0.071 \\
\hline \multicolumn{7}{|l|}{ Education level } \\
\hline Higher education & & & 0 & -- & 0 & -- \\
\hline No higher education & & & $-0.417(-1.429$ to 0.595$)$ & 0.42 & $-0.407(-1.441$ to 0.627$)$ & 0.44 \\
\hline \multicolumn{7}{|l|}{ Employment status } \\
\hline Employed full-time & & & 0 & -- & 0 & -- \\
\hline Employed part-time & & & $-0.165(-1.248$ to 0.919$)$ & 0.766 & $-0.149(-1.254$ to 0.957$)$ & 0.792 \\
\hline Home/Unemp/Retired & & & $-0.718(-2.615$ to 1.18$)$ & 0.458 & $-0.878(-2.825$ to 1.07$)$ & 0.377 \\
\hline Student/ in training & & & $-0.025(-1.401$ to 1.351$)$ & 0.971 & $0.007(-1.394$ to 1.407$)$ & 0.993 \\
\hline \multicolumn{7}{|l|}{ Driving licence } \\
\hline No & & & & & 0 & -- \\
\hline Yes & & & & & $0.106(-1.638$ to 1.85$)$ & 0.905 \\
\hline \multicolumn{7}{|l|}{ Car access } \\
\hline Never & & & & & 0 & -- \\
\hline Sometimes & & & & & $0.774(-0.647$ to 2.194$)$ & 0.286 \\
\hline Always & & & & & $0.568(-0.845$ to 1.98$)$ & 0.431 \\
\hline \multicolumn{7}{|l|}{ Bike access } \\
\hline No & & & & & 0 & -- \\
\hline Yes & & & & & $-0.424(-1.593$ to 0.746$)$ & 0.478 \\
\hline \multicolumn{7}{|l|}{ Self-rated health } \\
\hline Excellent & & & & & 0 & -- \\
\hline Very good & & & & & $0.439(-1.006$ to 1.884$)$ & 0.551 \\
\hline Good & & & & & $0.172(-1.293$ to 1.637$)$ & 0.818 \\
\hline Fair & & & & & $1.126(-0.843$ to 3.095$)$ & 0.262 \\
\hline Poor & & & & & 2.233 (-1.838 to 6.303$)$ & 0.282 \\
\hline Building-area density\# & & & & & $-0.01(-0.71$ to 0.691$)$ & 0.979 \\
\hline Street-length density\# & & & & & $-0.596(-1.779$ to 0.588$)$ & 0.324 \\
\hline \multicolumn{7}{|l|}{ Intersection dens. / } \\
\hline connectivity $\#$ & & & & & $0.282(-0.808$ to 1.372$)$ & 0.612 \\
\hline Facility richness index\# & & & & & $0.042(-0.646$ to 0.731$)$ & 0.904 \\
\hline PT stations density\# & & & & & $-0.173(-0.721$ to 0.375$)$ & 0.537 \\
\hline Dist. to nearest PT station" & & & & & $-0.074(-0.536$ to 0.389$)$ & 0.755 \\
\hline Dist. home to centre & & & & & $-0.03(-1.455$ to 1.395$)$ & 0.967 \\
\hline Dist. home to school ${ }^{\#}$ & & & & & 0.209 (-1.143 to 1.561$)$ & 0.762 \\
\hline Dist. Home to food ${ }^{\#}$ & & & & & $-0.233(-1.313$ to 0.846$)$ & 0.672 \\
\hline \multicolumn{7}{|l|}{ Travel time PT home to } \\
\hline centre $e^{\#}$ & & & & & $-0.382(-0.848$ to 0.084$)$ & 0.108 \\
\hline \multicolumn{7}{|l|}{ PT service frequency } \\
\hline (home) $)^{\#}$ & & & & & $-0.097(-0.528$ to 0.333$)$ & 0.658 \\
\hline Dist. home to work\# & & & & & $-0.179(-0.673$ to 0.315$)$ & 0.478 \\
\hline Time between $t_{0}$ and $t_{1}$ & & & & & 0.001 (-0.001 to 0.003$)$ & 0.365 \\
\hline
\end{tabular}

\# Built environment and PT accessibility variables were standardized (with mean=0 and SD=1). 
Table S7: Results for the association between change in lifecycle $\mathrm{CO}_{2}$ emissions (kg/day) and change in main mode of travel $(n=1849)$

\begin{tabular}{|c|c|c|c|c|c|c|}
\hline & \multicolumn{2}{|l|}{ Model 0: unadjusted } & \multicolumn{2}{|l|}{ Model 1: partly adjusted } & \multicolumn{2}{|l|}{ Model 2: fully adjusted } \\
\hline & Coefficient $(95 \% \mathrm{Cl})$ & $p$-value & Coefficient (95\% Cl) & $\mathrm{p}$-value & Coefficient (95\% Cl) & $\mathrm{p}$-value \\
\hline \multicolumn{7}{|l|}{ Change in main mode of travel } \\
\hline Stable: car & 0 & -- & 0 & -- & 0 & -- \\
\hline Active travel to car & 9.726 (7.729 to 11.723$)$ & $<0.0001$ & 9.626 (7.626 to 11.626$)$ & $<0.0001$ & 9.251 (7.223 to 11.279$)$ & $<0.0001$ \\
\hline Active travel to PT & 2.034 (0.236 to 3.833$)$ & 0.027 & 1.907 (0.101 to 3.713$)$ & 0.038 & $1.697(-0.204$ to 3.599$)$ & 0.05 \\
\hline Car to active travel & $-9.032(-11.178$ to -6.886$)$ & $<0.0001$ & $-9.081(-11.229$ to -6.932$)$ & $<0.0001$ & $-9.283(-11.459$ to -7.107$)$ & $<0.0001$ \\
\hline Car to PT & $-6.583(-8.867$ to -4.299$)$ & $<0.0001$ & $-6.638(-8.922$ to -4.354$)$ & $<0.0001$ & $-6.805(-9.117$ to -4.493$)$ & $<0.0001$ \\
\hline PT to active travel & $-3.37(-5.114$ to -1.625$)$ & $<0.0001$ & $-3.558(-5.317$ to -1.8$)$ & $<0.0001$ & $-3.724(-5.573$ to -1.875$)$ & $<0.0001$ \\
\hline PT to car & 4.927 (2.937 to 6.918$)$ & $<0.0001$ & 4.826 (2.829 to 6.822$)$ & $<0.0001$ & 4.875 (2.858 to 6.893 ) & $<0.0001$ \\
\hline Stable: active travel & $-0.646(-1.999$ to 0.706$)$ & 0.349 & $-0.702(-2.06$ to 0.656$)$ & 0.311 & $-1.041(-2.508$ to 0.426$)$ & 0.164 \\
\hline Stable: PT & $-0.631(-1.985$ to 0.723$)$ & 0.36 & $-0.727(-2.087$ to 0.634$)$ & 0.295 & $-0.768(-2.207$ to 0.671$)$ & 0.295 \\
\hline \multicolumn{7}{|l|}{ Sex } \\
\hline Male & & & 0 & -- & 0 & -- \\
\hline Female & & & $0.047(-0.768$ to 0.862$)$ & 0.91 & $-0.023(-0.855$ to 0.809$)$ & 0.957 \\
\hline Age at $t_{0}$ (years) & & & $-0.031(-0.071$ to 0.009$)$ & 0.133 & $-0.03(-0.073$ to 0.012$)$ & 0.16 \\
\hline \multicolumn{7}{|l|}{ Education level } \\
\hline Higher/university education & & & 0 & -- & 0 & -- \\
\hline No higher/univ. education & & & $-0.698(-1.694$ to 0.298$)$ & 0.169 & $-0.667(-1.68$ to 0.347$)$ & 0.197 \\
\hline \multicolumn{7}{|l|}{ Employment status } \\
\hline Employed full-time & & & 0 & -- & 0 & -- \\
\hline Employed part-time & & & $-0.139(-1.201$ to 0.924$)$ & 0.798 & $-0.166(-1.247$ to 0.915$)$ & 0.764 \\
\hline Home/Unemp./Retired & & & $-0.331(-2.195$ to 1.534$)$ & 0.728 & $-0.708(-2.623$ to 1.206$)$ & 0.468 \\
\hline Student/ in training & & & $0.193(-1.157$ to 1.544$)$ & 0.779 & $0.218(-1.153$ to 1.589$)$ & 0.755 \\
\hline \multicolumn{7}{|l|}{ Driving licence } \\
\hline No & & & & & 0 & -- \\
\hline Yes & & & & & $-0.102(-1.806$ to 1.602$)$ & 0.906 \\
\hline \multicolumn{7}{|l|}{ Car access } \\
\hline Never & & & & & 0 & -- \\
\hline Sometimes & & & & & 0.709 (-0.688 to 2.106$)$ & 0.32 \\
\hline Always & & & & & $0.26(-1.17$ to 1.691$)$ & 0.721 \\
\hline \multicolumn{7}{|l|}{ Bike access } \\
\hline No & & & & & 0 & -- \\
\hline Yes & & & & & $-0.036(-1.215$ to 1.142$)$ & 0.952 \\
\hline \multicolumn{7}{|l|}{ Self-rated health } \\
\hline Excellent & & & & & 0 & -- \\
\hline Very good & & & & & $0.311(-1.102$ to 1.724$)$ & 0.666 \\
\hline Good & & & & & $-0.014(-1.446$ to 1.418$)$ & 0.984 \\
\hline Fair & & & & & $0.683(-1.245$ to 2.611$)$ & 0.487 \\
\hline Poor & & & & & $2.201(-1.78$ to 6.181$)$ & 0.279 \\
\hline Building-area density ${ }^{\#}$ & & & & & $-0.008(-0.693$ to 0.677$)$ & 0.982 \\
\hline Street-length density & & & & & $-0.532(-1.692$ to 0.628$)$ & 0.369 \\
\hline Intersection dens. / connectivity\# & & & & & $0.207(-0.86$ to 1.274$)$ & 0.703 \\
\hline Facility richness index $\#$ & & & & & $0.101(-0.575$ to 0.777$)$ & 0.77 \\
\hline PT stations density ${ }^{\#}$ & & & & & $-0.087(-0.623$ to 0.45$)$ & 0.751 \\
\hline Dist. to nearest PT station ${ }^{\#}$ & & & & & $-0.066(-0.518$ to 0.387$)$ & 0.776 \\
\hline Dist. home to centre ${ }^{\#}$ & & & & & $-0.313(-1.713$ to 1.087$)$ & 0.661 \\
\hline Dist. home to school ${ }^{\#}$ & & & & & $0.566(-0.76$ to 1.892$)$ & 0.403 \\
\hline Dist. Home to food" & & & & & $-0.335(-1.395$ to 0.724$)$ & 0.535 \\
\hline Travel time PT home to centre & & & & & $-0.528(-0.983$ to -0.072$)$ & 0.023 \\
\hline PT service frequency (home) ${ }^{\#}$ & & & & & $-0.012(-0.435$ to 0.411$)$ & 0.956 \\
\hline Dist. home to work ${ }^{\#}$ & & & & & $-0.249(-0.742$ to 0.243$)$ & 0.321 \\
\hline Time between $t_{0}$ and $t_{1}$ & & & & & $0.001(-0.001$ to 0.003$)$ & 0.232 \\
\hline
\end{tabular}

\# Built environment and PT accessibility variables were standardized (mean=0 and $S D=1$ ). 
Table S8: Results for the association between change in $\mathrm{CO}_{2}$ emissions $\left(\mathrm{kgCO}_{2} / \mathrm{day}\right)$ and change in daily cycling trips $(n=1849)$

\begin{tabular}{|c|c|c|c|c|c|c|}
\hline & \multicolumn{2}{|l|}{ Model 0: unadjusted } & \multicolumn{2}{|l|}{ Model 1: partly adjusted } & \multicolumn{2}{|l|}{ Model 2: fully adjusted } \\
\hline & Coefficient $(95 \% \mathrm{Cl})$ & $\mathrm{p}$-value & Coefficient $(95 \% \mathrm{Cl})$ & $\mathrm{p}$-value & Coefficient $(95 \% \mathrm{Cl})$ & $\mathrm{p}$-value \\
\hline \multicolumn{7}{|l|}{ Change in daily cycling trips } \\
\hline Stable: cycling trips & 0 & -- & 0 & -- & 0 & -- \\
\hline Fewer cycling trips & 1.387 (0.189 to 2.585$)$ & 0.023 & 1.383 (0.184 to 2.583$)$ & 0.024 & 1.303 (0.048 to 2.558$)$ & 0.042 \\
\hline More cycling trips & $-1.73(-3.019$ to -0.441$)$ & 0.008 & $-1.781(-3.071$ to -0.49$)$ & 0.007 & $-1.733(-3.068$ to -0.398$)$ & 0.011 \\
\hline Far fewer cycling trips & $4.176(2.318$ to 6.034$)$ & $<0.0001$ & 4.179 (2.317 to 6.04$)$ & $<0.0001$ & 4.088 (2.176 to 5.999$)$ & $<0.0001$ \\
\hline Far more cycling trips & $-2.191(-4.498$ to 0.116$)$ & 0.063 & $-2.272(-4.584$ to 0.04$)$ & 0.054 & $-2.433(-4.784$ to -0.083$)$ & 0.042 \\
\hline \multicolumn{7}{|l|}{ Sex } \\
\hline Male & & & 0 & -- & 0 & -- \\
\hline Female & & & $0.008(-0.864$ to 0.881$)$ & 0.985 & $-0.06(-0.949$ to 0.83$)$ & 0.896 \\
\hline Age at $t_{0}$ (years) & & & $-0.035(-0.078$ to 0.008$)$ & 0.114 & $-0.04(-0.085$ to 0.006$)$ & 0.086 \\
\hline \multicolumn{7}{|l|}{ Education level } \\
\hline Higher/university education & & & 0 & -- & 0 & -- \\
\hline No higher/univ. education & & & $-0.585(-1.652$ to 0.481$)$ & 0.282 & $-0.566(-1.653$ to 0.521$)$ & 0.307 \\
\hline \multicolumn{7}{|l|}{ Employment status } \\
\hline Employed full-time & & & 0 & -- & 0 & -- \\
\hline Employed part-time & & & $-0.167(-1.308$ to 0.974$)$ & 0.774 & $-0.095(-1.257$ to 1.067$)$ & 0.872 \\
\hline Home/Unemp./Retired & & & $-0.718(-2.713$ to 1.277$)$ & 0.481 & $-1.107(-3.154$ to 0.939$)$ & 0.289 \\
\hline Student/ in training & & & $0.271(-1.175$ to 1.717$)$ & 0.713 & $0.363(-1.107$ to 1.834$)$ & 0.628 \\
\hline \multicolumn{7}{|l|}{ Driving licence } \\
\hline No & & & & & 0 & -- \\
\hline Yes & & & & & $0.259(-1.572$ to 2.091$)$ & 0.781 \\
\hline \multicolumn{7}{|l|}{ Car access } \\
\hline Never & & & & & 0 & -- \\
\hline Sometimes & & & & & $0.574(-0.919$ to 2.068$)$ & 0.451 \\
\hline Always & & & & & $0.499(-0.985$ to 1.983$)$ & 0.51 \\
\hline \multicolumn{7}{|l|}{ Bike access } \\
\hline No & & & & & 0 & -- \\
\hline Yes & & & & & $-0.652(-1.93$ to 0.625$)$ & 0.317 \\
\hline \multicolumn{7}{|l|}{ Self-rated health } \\
\hline Excellent & & & & & 0 & -- \\
\hline Very good & & & & & 0.503 (-1.015 to 2.022$)$ & 0.516 \\
\hline Good & & & & & $0.153(-1.385$ to 1.692$)$ & 0.845 \\
\hline Fair & & & & & $0.755(-1.314$ to 2.824$)$ & 0.474 \\
\hline Poor & & & & & $3.64(-0.629$ to 7.91$)$ & 0.095 \\
\hline Building-area density ${ }^{\#}$ & & & & & $0.044(-0.693$ to 0.781$)$ & 0.907 \\
\hline Street-length density ${ }^{\#}$ & & & & & $-0.609(-1.855$ to 0.637$)$ & 0.338 \\
\hline Intersection dens. / connectivity\# & & & & & $0.35(-0.796$ to 1.497$)$ & 0.549 \\
\hline Facility richness index $\#$ & & & & & $-0.078(-0.801$ to 0.646$)$ & 0.833 \\
\hline Public transport stations density\# & & & & & $0.056(-0.521$ to 0.632$)$ & 0.85 \\
\hline Dist. to nearest PT station ${ }^{\#}$ & & & & & $0.056(-0.43$ to 0.542$)$ & 0.822 \\
\hline Dist. home to centre ${ }^{\#}$ & & & & & $-0.294(-1.797$ to 1.208$)$ & 0.701 \\
\hline Dist. home to school ${ }^{\#}$ & & & & & $0.389(-1.032$ to 1.81$)$ & 0.591 \\
\hline Dist. Home to food" & & & & & $-0.103(-1.239$ to 1.034$)$ & 0.86 \\
\hline Travel time PT home to centre & & & & & $-0.532(-1.021$ to -0.043$)$ & 0.033 \\
\hline PT service frequency (home) ${ }^{\#}$ & & & & & $-0.042(-0.495$ to 0.411$)$ & 0.856 \\
\hline Dist. home to work" & & & & & $-0.274(-0.794$ to 0.246$)$ & 0.301 \\
\hline Time between $t_{0}$ and $t_{1}$ & & & & & $0.001(-0.001$ to 0.003$)$ & 0.3 \\
\hline
\end{tabular}

\# Built environment and PT accessibility variables were standardized (mean=0 and SD=1). 
Table S9: Results for the association between change in $\mathrm{CO}_{2}$ emissions $\left(\mathrm{kgCO}_{2} /\right.$ day) and change in cycling frequency categories $(n=1849)$

\begin{tabular}{|c|c|c|c|c|c|c|}
\hline & \multicolumn{2}{|l|}{ Model 0: unadjusted } & \multicolumn{2}{|l|}{ Model 1: partly adjusted } & \multicolumn{2}{|l|}{ Model 2: fully adjusted } \\
\hline & Coefficient $(95 \% \mathrm{Cl})$ & $\mathrm{p}$-value & Coefficient $(95 \% \mathrm{Cl})$ & $\mathrm{p}$-value & Coefficient $(95 \% \mathrm{Cl})$ & $\mathrm{p}$-value \\
\hline \multicolumn{7}{|l|}{ Change in daily cycling } \\
\hline Stable: not cycling & 0 & -- & 0 & -- & 0 & -- \\
\hline Stable: cycling & $-1.162(-2.348$ to 0.024$)$ & 0.055 & $-1.171(-2.368$ to 0.026$)$ & 0.055 & $-1.429(-2.714$ to -0.143$)$ & 0.029 \\
\hline Less cycling & 2.348 (1.183 to 3.513$)$ & $<0.0001$ & 2.353 (1.183 to 3.522$)$ & $<0.0001$ & 2.11 (0.86 to 3.359$)$ & 0.001 \\
\hline More cycling & $-2.366(-3.667$ to -1.066$)$ & $<0.0001$ & $-2.44(-3.745$ to -1.134$)$ & $<0.0001$ & $-2.535(-3.904$ to -1.166$)$ & $<0.0001$ \\
\hline \multicolumn{7}{|c|}{ e } \\
\hline Male & & & 0 & -- & 0 & -- \\
\hline Female & & & $-0.09(-0.965$ to 0.785$)$ & 0.84 & $-0.186(-1.079$ to 0.708$)$ & 0.684 \\
\hline Age at $t_{0}$ (years) & & & $-0.035(-0.078$ to 0.008$)$ & 0.113 & $-0.038(-0.084$ to 0.007$)$ & 0.096 \\
\hline \multicolumn{7}{|l|}{ Education level } \\
\hline Higher/university education & & & 0 & -- & 0 & -- \\
\hline No higher/univ. education & & & $-0.643(-1.709$ to 0.423$)$ & 0.237 & $-0.622(-1.708$ to 0.464$)$ & 0.262 \\
\hline \multicolumn{7}{|l|}{ Employment status } \\
\hline Employed full-time & & & 0 & -- & 0 & -- \\
\hline Employed part-time & & & $-0.132(-1.271$ to 1.006$)$ & 0.82 & $-0.103(-1.263$ to 1.056$)$ & 0.861 \\
\hline Home/Unemp./Retired & & & $-0.838(-2.834$ to 1.159$)$ & 0.411 & $-1.314(-3.365$ to 0.736$)$ & 0.209 \\
\hline Student/in training & & & $0.208(-1.237$ to 1.653$)$ & 0.778 & $0.267(-1.202$ to 1.736$)$ & 0.722 \\
\hline \multicolumn{7}{|l|}{ Driving licence } \\
\hline No & & & & & 0 & -- \\
\hline Yes & & & & & 0.262 (-1.568 to 2.092$)$ & 0.779 \\
\hline \multicolumn{7}{|l|}{ Car access } \\
\hline Never & & & & & 0 & -- \\
\hline Sometimes & & & & & $0.609(-0.882$ to 2.1$)$ & 0.423 \\
\hline Always & & & & & $0.37(-1.114$ to 1.854$)$ & 0.625 \\
\hline \multicolumn{7}{|l|}{ Bike access } \\
\hline No & & & & & 0 & -- \\
\hline Yes & & & & & $-0.309(-1.62$ to 1.003$)$ & 0.645 \\
\hline \multicolumn{7}{|l|}{ Self-rated health } \\
\hline Excellent & & & & & 0 & -- \\
\hline Very good & & & & & 0.517 (-1 to 2.033$)$ & 0.504 \\
\hline Good & & & & & $0.187(-1.35$ to 1.725$)$ & 0.811 \\
\hline Fair & & & & & $0.808(-1.259$ to 2.874$)$ & 0.444 \\
\hline Poor & & & & & $3.474(-0.792$ to 7.74$)$ & 0.11 \\
\hline Building-area density $\#$ & & & & & $0.083(-0.654$ to 0.819$)$ & 0.826 \\
\hline Street-length density ${ }^{\#}$ & & & & & $-0.62(-1.865$ to 0.625$)$ & 0.329 \\
\hline Intersection dens. / connectivity & & & & & $0.339(-0.806$ to 1.483$)$ & 0.562 \\
\hline Facility richness index $\#$ & & & & & $-0.109(-0.832$ to 0.613$)$ & 0.766 \\
\hline Public transport stations density\# & & & & & $0.019(-0.556$ to 0.594$)$ & 0.948 \\
\hline Dist. to nearest PT station ${ }^{\#}$ & & & & & $0.045(-0.441$ to 0.53$)$ & 0.857 \\
\hline Dist. home to centre & & & & & $-0.363(-1.866$ to 1.141$)$ & 0.636 \\
\hline Dist. home to school ${ }^{\#}$ & & & & & 0.414 (-1.008 to 1.835$)$ & 0.568 \\
\hline Dist. Home to food\# & & & & & $-0.081(-1.215$ to 1.052$)$ & 0.888 \\
\hline Travel time PT home to centre & & & & & $-0.505(-0.993$ to -0.016$)$ & 0.043 \\
\hline PT service frequency (home) ${ }^{\#}$ & & & & & $0.016(-0.436$ to 0.468$)$ & 0.944 \\
\hline Dist. home to work & & & & & $-0.357(-0.878$ to 0.163$)$ & 0.178 \\
\hline Time between $t_{0}$ and $t_{1}$ & & & & & $0.001(-0.001$ to 0.003$)$ & 0.275 \\
\hline
\end{tabular}

\# Built environment and PT accessibility variables were standardized (mean=0 and SD=1). 
136 Table S10: Results of the association between change in mobility-related lifecycle $\mathrm{CO}_{2}$ 137 emissions and change in transport mode usage, by trip purpose $(n=1849)$.

\begin{tabular}{|c|c|c|c|c|c|c|c|c|}
\hline & \multicolumn{2}{|l|}{ Work or education } & \multicolumn{2}{|l|}{ Business } & \multicolumn{2}{|l|}{ Social or recreational } & \multicolumn{2}{|c|}{$\begin{array}{l}\text { Shopping, personal business, escort, } \\
\text { or 'other' }\end{array}$} \\
\hline & Coefficient $(95 \% \mathrm{Cl})$ & $\mathrm{p}$-value & Coefficient $(95 \% \mathrm{Cl})$ & $p$-value & Coefficient $(95 \% \mathrm{Cl})$ & $p$-value & Coefficient $(95 \% \mathrm{Cl})$ & $p$-value \\
\hline \multicolumn{9}{|c|}{ Change in transport mode usage (trips by purpose per day) } \\
\hline Bike & $-0.114(-0.262$ to 0.034$)$ & 0.131 & $-0.058(-0.418$ to 0.303$)$ & 0.754 & $-0.265(-0.594$ to 0.063$)$ & 0.049 & $-0.004(-0.087$ to 0.078$)$ & 0.919 \\
\hline Car & 3.138 (2.918 to 3.359 ) & $<0.001$ & 3.318 (2.872 to 3.764$)$ & $<0.001$ & 3.005 (2.693 to 3.316$)$ & $<0.001$ & 1.374 (1.296 to 1.453$)$ & $<0.001$ \\
\hline PT & 0.694 (0.548 to 0.84$)$ & $<0.001$ & 1.349 (0.959 to 1.739$)$ & $<0.001$ & 1.049 (0.73 to 1.368$)$ & $<0.001$ & 0.505 (0.397 to 0.614$)$ & $<0.001$ \\
\hline Walk & $-0.234(-0.432$ to -0.035$)$ & 0.021 & $-0.183(-0.665$ to 0.299$)$ & 0.456 & $-0.204(-0.506$ to 0.099$)$ & 0.187 & $-0.061(-0.137$ to 0.015$)$ & 0.118 \\
\hline \multicolumn{9}{|l|}{ Sex } \\
\hline Male & 0 & -- & 0 & -- & 0 & -- & 0 & -- \\
\hline Female & $0.045(-0.241$ to 0.33$)$ & 0.759 & $0.029(-0.383$ to 0.44$)$ & 0.892 & $-0.113(-0.673$ to 0.448$)$ & 0.694 & $0.132(-0.017$ to 0.281$)$ & 0.083 \\
\hline Age at $t_{0}$ (years) & $-0.015(-0.03$ to -0.001$)$ & 0.042 & $-0.007(-0.028$ to 0.014$)$ & 0.51 & $-0.011(-0.039$ to 0.018$)$ & 0.452 & $-0.005(-0.013$ to 0.002$)$ & 0.175 \\
\hline \multicolumn{9}{|l|}{ Education level } \\
\hline Higher & 0 & -- & 0 & -- & 0 & -- & 0 & -- \\
\hline No higher & $-0.012(-0.361$ to 0.338$)$ & 0.947 & $-0.53(-1.032$ to -0.028$)$ & 0.038 & $0.237(-0.447$ to 0.921$)$ & 0.497 & $-0.051(-0.235$ to 0.132$)$ & 0.585 \\
\hline \multicolumn{9}{|l|}{ Employment status } \\
\hline Employed F/T & 0 & -- & 0 & -- & 0 & -- & 0 & -- \\
\hline Employed P/T & $-0.047(-0.42$ to 0.326$)$ & 0.805 & $-0.131(-0.668$ to 0.406$)$ & 0.634 & $-0.056(-0.788$ to 0.676$)$ & 0.881 & $-0.021(-0.218$ to 0.176$)$ & 0.836 \\
\hline $\mathrm{Hm} / \mathrm{Un} / \mathrm{Ret} / \mathrm{L}$. & $-0.496(-1.155$ to 0.163$)$ & 0.14 & $-0.21(-1.158$ to 0.737$)$ & 0.664 & $-0.235(-1.524$ to 1.055$)$ & 0.721 & $-0.034(-0.377$ to 0.308$)$ & 0.844 \\
\hline Stud/Train & $0.013(-0.459$ to 0.486$)$ & 0.955 & $-0.005(-0.685$ to 0.675$)$ & 0.988 & $0.045(-0.882$ to 0.973$)$ & 0.924 & $-0.195(-0.442$ to 0.052$)$ & 0.121 \\
\hline \multicolumn{9}{|l|}{ Driving licence } \\
\hline No & 0 & -- & 0 & -- & 0 & -- & 0 & -- \\
\hline Yes & $0.152(-0.437$ to 0.741$)$ & 0.614 & $0.092(-0.755$ to 0.939$)$ & 0.831 & $-0.352(-1.506$ to 0.802$)$ & 0.55 & $0.216(-0.091$ to 0.522$)$ & 0.168 \\
\hline \multicolumn{9}{|l|}{ Car access } \\
\hline Never & 0 & -- & 0 & -- & 0 & -- & 0 & -- \\
\hline Sometimes & $0.051(-0.429$ to 0.531$)$ & 0.835 & $-0.088(-0.779$ to 0.602$)$ & 0.802 & $0.702(-0.238$ to 1.642$)$ & 0.143 & $0.089(-0.162$ to 0.339$)$ & 0.488 \\
\hline Always & $0.244(-0.234$ to 0.721$)$ & 0.317 & $-0.147(-0.834$ to 0.539$)$ & 0.674 & $0.627(-0.308$ to 1.562$)$ & 0.189 & $-0.046(-0.296$ to 0.204$)$ & 0.719 \\
\hline \multicolumn{9}{|l|}{ Bike access } \\
\hline No & 0 & -- & 0 & -- & 0 & -- & 0 & -- \\
\hline Yes & $0.16(-0.234$ to 0.554$)$ & 0.426 & $-0.207(-0.773$ to 0.36$)$ & 0.475 & $-0.088(-0.862$ to 0.685$)$ & 0.823 & $-0.147(-0.355$ to 0.061$)$ & 0.165 \\
\hline \multicolumn{9}{|l|}{ Self-rated health } \\
\hline Excellent & 0 & -- & 0 & -- & 0 & -- & 0 & -- \\
\hline Very good & $-0.092(-0.58$ to 0.396$)$ & 0.712 & $0.259(-0.443$ to 0.961$)$ & 0.47 & $0.074(-0.882$ to 1.03$)$ & 0.879 & $0.128(-0.126$ to 0.381$)$ & 0.323 \\
\hline Good & $0.168(-0.326$ to 0.663$)$ & 0.505 & $-0.04(-0.751$ to 0.671$)$ & 0.913 & $-0.159(-1.128$ to 0.809$)$ & 0.747 & $0.049(-0.208$ to 0.306$)$ & 0.707 \\
\hline Fair & $0.113(-0.552$ to 0.777$)$ & 0.74 & $0.531(-0.426$ to 1.488$)$ & 0.277 & $0.117(-1.187$ to 1.421$)$ & 0.861 & 0.207 (-0.139 to 0.553$)$ & 0.24 \\
\hline Poor & $1.053(-0.321$ to 2.427$)$ & 0.133 & $0.63(-1.345$ to 2.604$)$ & 0.532 & 0.251 ( -2.438 to 2.94$)$ & 0.855 & $0.282(-0.431$ to 0.995$)$ & 0.438 \\
\hline Building density" & $0.133(-0.103$ to 0.37$)$ & 0.27 & $-0.285(-0.625$ to 0.055$)$ & 0.101 & $0.197(-0.267$ to 0.66$)$ & 0.406 & $-0.078(-0.214$ to 0.058$)$ & 0.263 \\
\hline Street-len. density ${ }^{\#}$ & $-0.186(-0.587$ to 0.214$)$ & 0.361 & $0.029(-0.546$ to 0.604$)$ & 0.922 & $-0.459(-1.242$ to 0.324$)$ & 0.251 & $0.076(-0.133$ to 0.284$)$ & 0.478 \\
\hline Connectivity\# & 0.191 (-0.177 to 0.559$)$ & 0.309 & $-0.145(-0.675$ to 0.385$)$ & 0.591 & $0.272(-0.45$ to 0.993$)$ & 0.46 & $-0.077(-0.271$ to 0.116$)$ & 0.434 \\
\hline Facility richness $\#$ & $-0.047(-0.28$ to 0.185$)$ & 0.691 & $0.145(-0.19$ to 0.48$)$ & 0.397 & $-0.094(-0.549$ to 0.362$)$ & 0.687 & $0.032(-0.093$ to 0.157$)$ & 0.62 \\
\hline PT stations density ${ }^{\#}$ & $-0.004(-0.189$ to 0.181$)$ & 0.963 & $0.067(-0.199$ to 0.333$)$ & 0.621 & $-0.161(-0.524$ to 0.203$)$ & 0.386 & $-0.066(-0.164$ to 0.033$)$ & 0.191 \\
\hline Dist. PT station\# & $0.144(-0.012$ to 0.3$)$ & 0.071 & $-0.092(-0.316$ to 0.132$)$ & 0.422 & $-0.205(-0.511$ to 0.101$)$ & 0.189 & $0.007(-0.074$ to 0.088$)$ & 0.869 \\
\hline Dist. home-centre & $-0.184(-0.666$ to 0.298$)$ & 0.455 & $0.648(-0.045$ to 1.34$)$ & 0.067 & $-0.456(-1.4$ to 0.488$)$ & 0.344 & $-0.001(-0.254$ to 0.252$)$ & 0.993 \\
\hline Dist. home-school ${ }^{\#}$ & $0.192(-0.265$ to 0.649$)$ & 0.41 & $-0.426(-1.084$ to 0.232$)$ & 0.204 & $0.327(-0.569$ to 1.223$)$ & 0.474 & $-0.048(-0.295$ to 0.2$)$ & 0.706 \\
\hline Dist. home-food" & $-0.22(-0.585$ to 0.145$)$ & 0.237 & $-0.045(-0.57$ to 0.48$)$ & 0.866 & $0.15(-0.565$ to 0.864$)$ & 0.681 & $0.04(-0.161$ to 0.241$)$ & 0.699 \\
\hline Time PT to centre ${ }^{\#}$ & $0.017(-0.14$ to 0.175$)$ & 0.83 & $-0.428(-0.654$ to -0.201$)$ & $<0.001$ & $0.01(-0.298$ to 0.318$)$ & 0.95 & $-0.01(-0.097$ to 0.076$)$ & 0.819 \\
\hline PT service freq. ${ }^{\#}$ & $-0.019(-0.164$ to 0.127$)$ & 0.801 & $-0.003(-0.212$ to 0.206$)$ & 0.978 & $-0.075(-0.36$ to 0.211$)$ & 0.609 & $0.068(-0.013$ to 0.149$)$ & 0.101 \\
\hline Dist. home-work\# & $-0.168(-0.335$ to -0.002$)$ & 0.048 & $0.02(-0.22$ to 0.26$)$ & 0.869 & $-0.059(-0.386$ to 0.267$)$ & 0.722 & $0.022(-0.064$ to 0.109$)$ & 0.613 \\
\hline Time $t_{0}$ to $t_{1}$ & $0(-0.001$ to 0$)$ & 0.297 & 0.001 (0 to 0.002$)$ & 0.188 & $0(-0.001$ to 0.001$)$ & 0.875 & $0(0$ to 0.001$)$ & 0.112 \\
\hline
\end{tabular}

\# Built environment and PT accessibility variables were standardized (with mean=0 and SD=1). 

emissions and change in main mode of transport, by trip purpose $(n=1849)$.

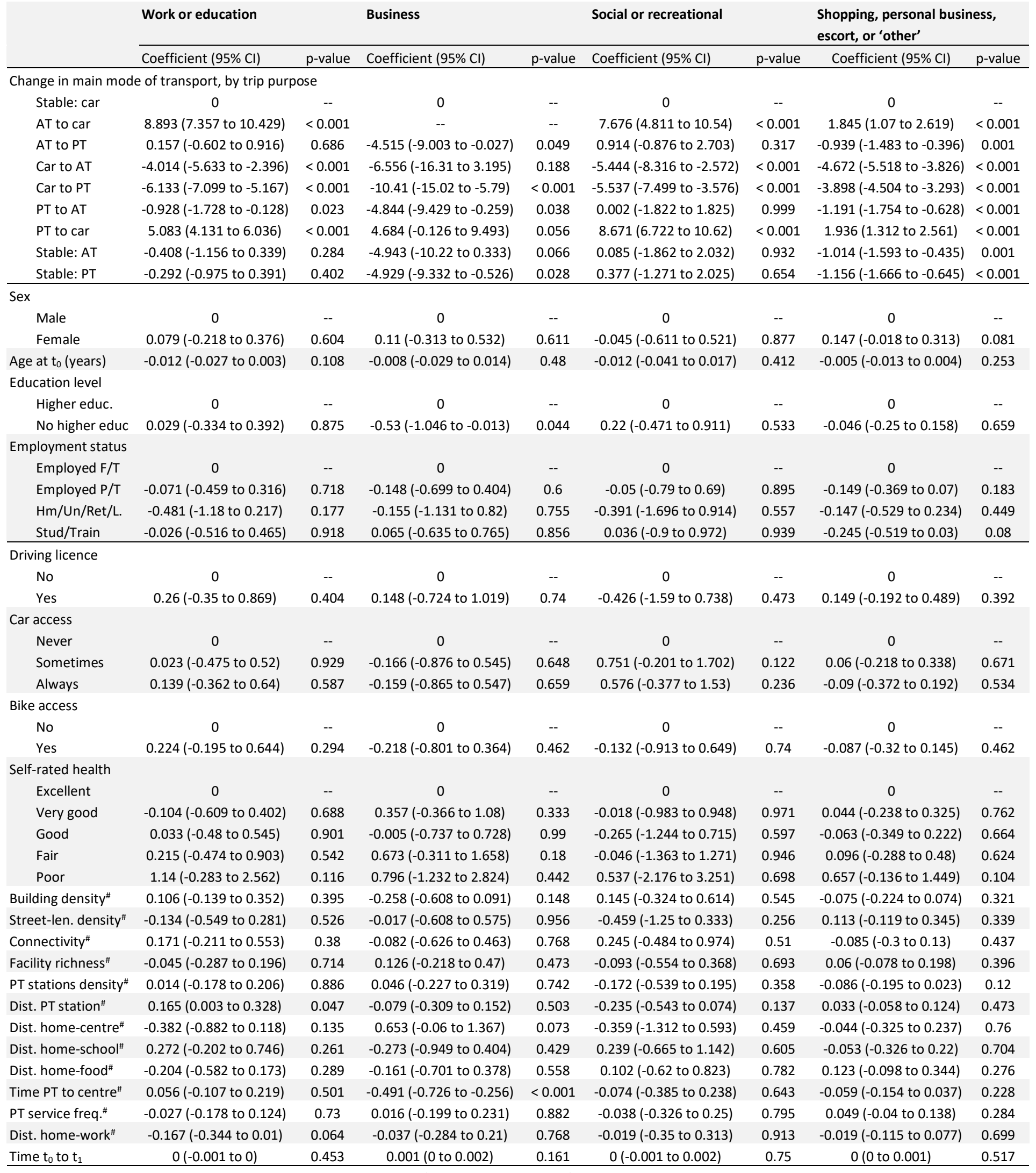

\# Built environment and PT accessibility variables were standardized (with mean 0 and $S D=1$ ). 
Table S12: Results of the association between change in mobility-related lifecycle $\mathrm{CO}_{2}$ emissions and change in daily cycling trips by trip purpose $(n=1849)$.

\begin{tabular}{|c|c|c|c|c|c|c|c|c|}
\hline & \multicolumn{2}{|l|}{ Work or education } & \multicolumn{2}{|l|}{ Business } & \multicolumn{2}{|l|}{ Social or recreational } & \multicolumn{2}{|c|}{$\begin{array}{l}\text { Shopping, personal business, } \\
\text { escort, or 'other' }\end{array}$} \\
\hline & Coefficient $(95 \% \mathrm{Cl})$ & $\begin{array}{c}p- \\
\text { value }\end{array}$ & Coefficient $(95 \% \mathrm{Cl})$ & $\begin{array}{c}\mathrm{p}- \\
\text { value }\end{array}$ & Coefficient $(95 \% \mathrm{Cl})$ & $\begin{array}{c}p- \\
\text { value }\end{array}$ & Coefficient $(95 \% \mathrm{Cl})$ & $\begin{array}{c}p- \\
\text { value }\end{array}$ \\
\hline \multicolumn{9}{|c|}{ Change in daily cycling trips by trip purpose } \\
\hline Stable bike & 0 & -- & 0 & -- & 0 & -- & 0 & -- \\
\hline Fewer trips & $0.252(-0.434$ to 0.938$)$ & 0.471 & $0.426(-1.864$ to 2.715$)$ & 0.716 & $0.325(-1.459$ to 2.108$)$ & 0.721 & $-0.271(-0.784$ to 0.242$)$ & 0.3 \\
\hline More trips & $-0.45(-1.149$ to 0.249$)$ & 0.207 & $0.333(-3.105$ to 3.77$)$ & 0.849 & $-0.639(-2.591$ to 1.312$)$ & 0.521 & $0.362(-0.215$ to 0.939$)$ & 0.218 \\
\hline Far fewer trips & 0.686 (0.126 to 1.246$)$ & 0.016 & $0.637(-0.674$ to 1.949$)$ & 0.341 & $0.985(-0.255$ to 2.224$)$ & 0.119 & $-0.1(-0.49$ to 0.289$)$ & 0.614 \\
\hline Far more trips & $-0.872(-1.514$ to -0.231$)$ & 0.008 & $0.239(-1.494$ to 1.972$)$ & 0.787 & $-0.537(-1.786$ to 0.712$)$ & 0.399 & $-0.527(-0.944$ to -0.11$)$ & 0.013 \\
\hline \multicolumn{9}{|l|}{ Sex } \\
\hline Male & 0 & -- & 0 & -- & 0 & -- & 0 & -- \\
\hline Female & $-0.075(-0.419$ to 0.27$)$ & 0.671 & $0.152(-0.288$ to 0.592$)$ & 0.499 & $-0.232(-0.853$ to 0.388$)$ & 0.463 & $0.149(-0.045$ to 0.343$)$ & 0.131 \\
\hline Age at $t_{0}$ (years) & $-0.017(-0.034$ to 0.001$)$ & 0.064 & $-0.009(-0.032$ to 0.013$)$ & 0.41 & $-0.006(-0.037$ to 0.025$)$ & 0.706 & $-0.006(-0.016$ to 0.004$)$ & 0.254 \\
\hline \multicolumn{9}{|l|}{ Education level } \\
\hline Higher educ. & 0 & -- & 0 & -- & 0 & -- & 0 & -- \\
\hline No higher educ & $-0.087(-0.508$ to 0.334$)$ & 0.685 & $-0.618(-1.155$ to -0.08$)$ & 0.024 & $0.123(-0.633$ to 0.879$)$ & 0.75 & $-0.063(-0.301$ to 0.174$)$ & 0.602 \\
\hline \multicolumn{9}{|l|}{ Employment status } \\
\hline Employed F/T & 0 & -- & 0 & -- & 0 & -- & 0 & -- \\
\hline Employed P/T & 0.089 (-0.36 to 0.539$)$ & 0.697 & $-0.145(-0.721$ to 0.43$)$ & 0.621 & $0.102(-0.707$ to 0.911$)$ & 0.804 & $-0.142(-0.398$ to 0.114$)$ & 0.278 \\
\hline $\mathrm{Hm} / \mathrm{Un} / \mathrm{Ret} / \mathrm{L}$. & $-0.43(-1.227$ to 0.367$)$ & 0.291 & $0.044(-0.97$ to 1.057$)$ & 0.933 & $-0.555(-1.98$ to 0.87$)$ & 0.445 & $-0.126(-0.572$ to 0.32$)$ & 0.58 \\
\hline Stud/Train & $-0.022(-0.592$ to 0.548$)$ & 0.939 & $0.183(-0.545$ to 0.911$)$ & 0.623 & 0.325 (-0.698 to 1.349$)$ & 0.533 & $-0.202(-0.522$ to 0.119$)$ & 0.217 \\
\hline \multicolumn{9}{|l|}{ Driving licence } \\
\hline No & 0 & -- & 0 & -- & 0 & -- & 0 & -- \\
\hline Yes & $0.229(-0.481$ to 0.939$)$ & 0.526 & $0.109(-0.798$ to 1.015$)$ & 0.814 & $-0.393(-1.67$ to 0.884$)$ & 0.546 & 0.199 (-0.2 to 0.597$)$ & 0.328 \\
\hline \multicolumn{9}{|l|}{ Car access } \\
\hline Never & 0 & -- & 0 & -- & 0 & -- & 0 & -- \\
\hline Sometimes & $0.115(-0.465$ to 0.694$)$ & 0.698 & $-0.112(-0.852$ to 0.628$)$ & 0.767 & $0.628(-0.412$ to 1.668$)$ & 0.237 & $0.041(-0.285$ to 0.367$)$ & 0.805 \\
\hline Always & $0.199(-0.377$ to 0.775$)$ & 0.498 & $-0.133(-0.868$ to 0.602$)$ & 0.722 & $0.511(-0.523$ to 1.546$)$ & 0.333 & $-0.016(-0.341$ to 0.308$)$ & 0.922 \\
\hline \multicolumn{9}{|l|}{ Bike access } \\
\hline No & 0 & -- & 0 & -- & 0 & -- & 0 & -- \\
\hline Yes & $0.056(-0.434$ to 0.546$)$ & 0.821 & $-0.217(-0.825$ to 0.391$)$ & 0.484 & $-0.36(-1.225$ to 0.505$)$ & 0.415 & $-0.001(-0.273$ to 0.271$)$ & 0.994 \\
\hline \multicolumn{9}{|l|}{ Self-rated health } \\
\hline Excellent & 0 & -- & 0 & -- & 0 & -- & 0 & -- \\
\hline Very good & $0.02(-0.568$ to 0.609$)$ & 0.947 & $0.293(-0.458$ to 1.044$)$ & 0.445 & $0.028(-1.028$ to 1.084$)$ & 0.958 & $0.129(-0.2$ to 0.458$)$ & 0.442 \\
\hline Good & $0.281(-0.317$ to 0.878$)$ & 0.357 & $-0.015(-0.776$ to 0.747$)$ & 0.969 & $-0.141(-1.211$ to 0.93$)$ & 0.797 & $-0.067(-0.401$ to 0.267$)$ & 0.695 \\
\hline Fair & $0.239(-0.563$ to 1.041$)$ & 0.56 & $0.666(-0.359$ to 1.691$)$ & 0.203 & $-0.209(-1.65$ to 1.231$)$ & 0.776 & $0.048(-0.402$ to 0.498$)$ & 0.834 \\
\hline Poor & $1.482(-0.174$ to 3.137$)$ & 0.079 & 0.795 (-1.317 to 2.907$)$ & 0.461 & $0.59(-2.382$ to 3.563$)$ & 0.697 & $0.85(-0.075$ to 1.776$)$ & 0.072 \\
\hline Building density\# & $0.158(-0.127$ to 0.443$)$ & 0.276 & $-0.283(-0.647$ to 0.081$)$ & 0.127 & $0.233(-0.28$ to 0.746$)$ & 0.374 & $-0.04(-0.212$ to 0.133$)$ & 0.65 \\
\hline Street-len. density $\#$ & $-0.1(-0.583$ to 0.382$)$ & 0.683 & $-0.03(-0.645$ to 0.585$)$ & 0.924 & $-0.661(-1.527$ to 0.204$)$ & 0.134 & $0.087(-0.184$ to 0.358$)$ & 0.529 \\
\hline Connectivity & $0.137(-0.307$ to 0.581$)$ & 0.546 & $-0.061(-0.627$ to 0.505$)$ & 0.833 & $0.451(-0.346$ to 1.248$)$ & 0.268 & $-0.083(-0.333$ to 0.168$)$ & 0.519 \\
\hline Facility richness $\#$ & $-0.086(-0.367$ to 0.195$)$ & 0.548 & $0.108(-0.25$ to 0.466$)$ & 0.554 & $-0.168(-0.671$ to 0.336$)$ & 0.514 & $0.005(-0.156$ to 0.166$)$ & 0.949 \\
\hline PT stations density & $0.067(-0.156$ to 0.29$)$ & 0.558 & $0.028(-0.257$ to 0.312$)$ & 0.848 & $-0.1(-0.5$ to 0.301$)$ & 0.625 & $-0.001(-0.128$ to 0.126$)$ & 0.989 \\
\hline Dist. PT station" & $0.168(-0.02$ to 0.357$)$ & 0.08 & $-0.103(-0.343$ to 0.137$)$ & 0.398 & $-0.073(-0.41$ to 0.265$)$ & 0.673 & $0.007(-0.098$ to 0.113$)$ & 0.894 \\
\hline Dist. home-centre ${ }^{\#}$ & $-0.115(-0.697$ to 0.467$)$ & 0.698 & $0.572(-0.17$ to 1.313$)$ & 0.131 & $-0.749(-1.792$ to 0.294$)$ & 0.159 & $-0.01(-0.337$ to 0.318$)$ & 0.955 \\
\hline Dist. home-school" & $0.1(-0.451$ to 0.651$)$ & 0.722 & $-0.218(-0.921$ to 0.485$)$ & 0.543 & 0.589 (-0.399 to 1.577$)$ & 0.243 & $-0.115(-0.433$ to 0.202$)$ & 0.476 \\
\hline \multirow[t]{2}{*}{ Dist. home-food ${ }^{\#}$} & $-0.264(-0.704$ to 0.176$)$ & 0.239 & $-0.251(-0.812$ to 0.311$)$ & 0.382 & $0.299(-0.491$ to 1.089$)$ & 0.459 & $0.143(-0.113$ to 0.4$)$ & 0.274 \\
\hline & & & & $<$ & & & & \\
\hline Time PT to centre ${ }^{\#}$ & $0.042(-0.148$ to 0.232$)$ & 0.663 & $-0.449(-0.691$ to -0.207$)$ & 0.001 & $-0.035(-0.376$ to 0.305$)$ & 0.839 & $-0.092(-0.203$ to 0.018$)$ & 0.102 \\
\hline PT service freq." & $0.02(-0.155$ to 0.196$)$ & 0.821 & $0.014(-0.21$ to 0.238$)$ & 0.904 & $-0.151(-0.467$ to 0.164$)$ & 0.347 & 0.121 (0.018 to 0.225$)$ & 0.022 \\
\hline Dist. home-work ${ }^{\#}$ & $-0.253(-0.455$ to -0.051$)$ & 0.014 & $0.032(-0.225$ to 0.289$)$ & 0.807 & $-0.065(-0.426$ to 0.296$)$ & 0.724 & $-0.026(-0.139$ to 0.087$)$ & 0.65 \\
\hline Time $t_{0}$ to $t_{1}$ & $0(-0.001$ to 0$)$ & 0.341 & 0.001 (0 to 0.002 ) & 0.156 & $0.001(-0.001$ to 0.002$)$ & 0.461 & $0(0$ to 0.001$)$ & 0.605 \\
\hline
\end{tabular}

\# Built environment and PT accessibility variables were standardized (with mean $=0$ and $S D=1$ ). 
Table S13: Results of the association between change in mobility-related lifecycle $\mathrm{CO}_{2}$ emissions and change in cycling frequency categories by trip purpose $(n=1849)$.

\begin{tabular}{|c|c|c|c|c|c|c|c|c|}
\hline & \multicolumn{2}{|l|}{ Work or education } & \multicolumn{2}{|l|}{ Business } & \multicolumn{2}{|l|}{ Social or recreational } & \multicolumn{2}{|c|}{$\begin{array}{l}\text { Shopping, personal business, } \\
\text { escort, or 'other' }\end{array}$} \\
\hline & Coefficient $(95 \% \mathrm{Cl})$ & $\mathrm{p}$-value & Coefficient $(95 \% \mathrm{Cl})$ & p-value & Coefficient $(95 \% \mathrm{Cl})$ & $\mathrm{p}$-value & Coefficient $(95 \% \mathrm{Cl})$ & $p$-value \\
\hline \multicolumn{9}{|c|}{ Change in cycling frequency categories by trip purpose } \\
\hline Stable not cycl. & 0 & -- & 0 & -- & 0 & -- & 0 & -- \\
\hline Stable cycling & $0.05(-0.478$ to 0.578$)$ & 0.853 & $0.12(-3.949$ to 4.189$)$ & 0.954 & $-0.191(-1.785$ to 1.403$)$ & 0.815 & $-0.334(-0.902$ to 0.234$)$ & 0.249 \\
\hline Less cycling & $0.883(0.355$ to 1.411$)$ & 0.001 & $0.626(-0.616$ to 1.869$)$ & 0.323 & $0.804(-0.359$ to 1.967$)$ & 0.175 & $-0.101(-0.445$ to 0.242$)$ & 0.564 \\
\hline More cycling & $-0.654(-1.247$ to -0.061$)$ & 0.031 & $0.264(-1.335$ to 1.862$)$ & 0.746 & $-0.5(-1.653$ to 0.653$)$ & 0.395 & $-0.22(-0.607$ to 0.167$)$ & 0.266 \\
\hline \multicolumn{9}{|l|}{ Sex } \\
\hline Male & 0 & -- & 0 & -- & 0 & -- & 0 & -- \\
\hline Female & $-0.072(-0.417$ to 0.273$)$ & 0.683 & $0.15(-0.289$ to 0.59$)$ & 0.503 & $-0.232(-0.852$ to 0.387$)$ & 0.463 & 0.154 (-0.04 to 0.348$)$ & 0.12 \\
\hline Age at $t_{0}$ (years) & $-0.016(-0.034$ to 0.001$)$ & 0.065 & $-0.009(-0.032$ to 0.013$)$ & 0.414 & $-0.006(-0.038$ to 0.025$)$ & 0.704 & $-0.005(-0.015$ to 0.004$)$ & 0.287 \\
\hline \multicolumn{9}{|l|}{ Education level } \\
\hline Higher educ. & 0 & -- & 0 & -- & 0 & -- & 0 & -- \\
\hline No higher educ & $-0.061(-0.483$ to 0.36$)$ & 0.775 & $-0.616(-1.154$ to -0.079$)$ & 0.025 & $0.131(-0.625$ to 0.886$)$ & 0.735 & $-0.066(-0.304$ to 0.172$)$ & 0.586 \\
\hline \multicolumn{9}{|l|}{ Employment status } \\
\hline Employed F/T & 0 & -- & 0 & -- & 0 & -- & 0 & -- \\
\hline Employed P/T & $0.119(-0.331$ to 0.569$)$ & 0.605 & $-0.139(-0.714$ to 0.436$)$ & 0.636 & $0.109(-0.7$ to 0.918$)$ & 0.792 & $-0.149(-0.405$ to 0.107$)$ & 0.255 \\
\hline $\mathrm{Hm} / \mathrm{Un} / \mathrm{Ret} / \mathrm{L}$. & $-0.38(-1.183$ to 0.424$)$ & 0.354 & 0.04 (-0.973 to 1.053$)$ & 0.938 & $-0.563(-1.986$ to 0.861$)$ & 0.438 & $-0.094(-0.539$ to 0.352$)$ & 0.681 \\
\hline Stud/Train & $-0.013(-0.583$ to 0.557$)$ & 0.963 & $0.184(-0.544$ to 0.911$)$ & 0.621 & $0.327(-0.696$ to 1.351$)$ & 0.531 & $-0.186(-0.506$ to 0.135$)$ & 0.257 \\
\hline \multicolumn{9}{|l|}{ Driving licence } \\
\hline No & 0 & -- & 0 & -- & 0 & -- & 0 & -- \\
\hline Yes & $0.217(-0.492$ to 0.926$)$ & 0.549 & $0.113(-0.794$ to 1.021$)$ & 0.807 & $-0.383(-1.657$ to 0.891$)$ & 0.555 & $0.178(-0.22$ to 0.577$)$ & 0.381 \\
\hline \multicolumn{9}{|l|}{ Car access } \\
\hline Never & 0 & -- & 0 & -- & 0 & -- & 0 & -- \\
\hline Sometimes & $0.107(-0.471$ to 0.685$)$ & 0.717 & $-0.116(-0.857$ to 0.625$)$ & 0.76 & $0.636(-0.403$ to 1.675$)$ & 0.23 & $0.039(-0.286$ to 0.365$)$ & 0.812 \\
\hline Always & $0.196(-0.378$ to 0.771$)$ & 0.503 & $-0.136(-0.871$ to 0.598$)$ & 0.716 & $0.525(-0.508$ to 1.558$)$ & 0.32 & $-0.007(-0.332$ to 0.317$)$ & 0.964 \\
\hline \multicolumn{9}{|l|}{ Bike access } \\
\hline No & 0 & -- & 0 & -- & 0 & -- & 0 & -- \\
\hline Yes & $-0.011(-0.504$ to 0.482$)$ & 0.965 & $-0.216(-0.824$ to 0.391$)$ & 0.486 & $-0.354(-1.219$ to 0.512$)$ & 0.424 & $-0.001(-0.274$ to 0.272$)$ & 0.994 \\
\hline \multicolumn{9}{|l|}{ Self-rated health } \\
\hline Excellent & 0 & -- & 0 & -- & 0 & -- & 0 & -- \\
\hline Very good & $0.02(-0.568$ to 0.608$)$ & 0.947 & 0.291 (-0.46 to 1.042$)$ & 0.448 & $0.036(-1.02$ to 1.092$)$ & 0.947 & $0.133(-0.197$ to 0.462$)$ & 0.429 \\
\hline Good & 0.28 (-0.316 to 0.876$)$ & 0.357 & $-0.016(-0.777$ to 0.745$)$ & 0.968 & $-0.136(-1.207$ to 0.934$)$ & 0.803 & $-0.068(-0.403$ to 0.266$)$ & 0.689 \\
\hline Fair & 0.249 (-0.551 to 1.05$)$ & 0.542 & $0.666(-0.359$ to 1.69$)$ & 0.203 & $-0.19(-1.63$ to 1.25$)$ & 0.796 & 0.039 (-0.41 to 0.489$)$ & 0.864 \\
\hline Poor & $1.523(-0.132$ to 3.178$)$ & 0.071 & $0.793(-1.318$ to 2.904$)$ & 0.462 & $0.614(-2.358$ to 3.587$)$ & 0.686 & $0.839(-0.088$ to 1.766$)$ & 0.076 \\
\hline Building density” & $0.156(-0.129$ to 0.441$)$ & 0.284 & $-0.284(-0.648$ to 0.08$)$ & 0.126 & $0.232(-0.28$ to 0.745$)$ & 0.374 & $-0.037(-0.21$ to 0.137$)$ & 0.678 \\
\hline Street-len. density ${ }^{\#}$ & $-0.079(-0.562$ to 0.403$)$ & 0.747 & $-0.031(-0.646$ to 0.584$)$ & 0.922 & $-0.657(-1.523$ to 0.208$)$ & 0.137 & $0.096(-0.176$ to 0.367$)$ & 0.489 \\
\hline Connectivity $\#$ & $0.116(-0.328$ to 0.56$)$ & 0.608 & $-0.06(-0.627$ to 0.506$)$ & 0.835 & $0.443(-0.355$ to 1.241$)$ & 0.276 & $-0.087(-0.338$ to 0.164$)$ & 0.499 \\
\hline Facility richness $\#$ & $-0.085(-0.365$ to 0.195$)$ & 0.554 & $0.107(-0.251$ to 0.464$)$ & 0.559 & $-0.167(-0.671$ to 0.336$)$ & 0.515 & $-0.004(-0.165$ to 0.158$)$ & 0.966 \\
\hline PT stations density\# & $0.069(-0.154$ to 0.292$)$ & 0.544 & $0.028(-0.256$ to 0.312$)$ & 0.847 & $-0.101(-0.501$ to 0.3$)$ & 0.622 & 0 (-0.127 to 0.127$)$ & 0.997 \\
\hline Dist. PT station" & $0.175(-0.013$ to 0.364$)$ & 0.068 & $-0.104(-0.343$ to 0.136$)$ & 0.398 & $-0.077(-0.415$ to 0.261$)$ & 0.654 & $0.009(-0.097$ to 0.115$)$ & 0.866 \\
\hline Dist. home-centre ${ }^{\#}$ & $-0.098(-0.679$ to 0.484$)$ & 0.742 & 0.569 (-0.171 to 1.309$)$ & 0.132 & $-0.751(-1.794$ to 0.292$)$ & 0.158 & $-0.008(-0.337$ to 0.32$)$ & 0.961 \\
\hline Dist. home-school ${ }^{\#}$ & 0.09 (-0.461 to 0.641$)$ & 0.75 & $-0.218(-0.92$ to 0.485$)$ & 0.544 & $0.583(-0.405$ to 1.571$)$ & 0.247 & $-0.115(-0.433$ to 0.204$)$ & 0.479 \\
\hline Dist. home-food\# & $-0.262(-0.702$ to 0.177$)$ & 0.242 & $-0.248(-0.809$ to 0.313$)$ & 0.386 & $0.304(-0.486$ to 1.094$)$ & 0.45 & $0.141(-0.116$ to 0.399$)$ & 0.283 \\
\hline Time PT to centre ${ }^{\#}$ & $0.039(-0.151$ to 0.229$)$ & 0.686 & $-0.45(-0.692$ to -0.208$)$ & 0 & $-0.036(-0.376$ to 0.304$)$ & 0.835 & $-0.087(-0.198$ to 0.024$)$ & 0.125 \\
\hline PT service freq. ${ }^{\#}$ & $0.022(-0.154$ to 0.197$)$ & 0.81 & $0.013(-0.211$ to 0.237$)$ & 0.906 & $-0.149(-0.465$ to 0.166$)$ & 0.353 & 0.119 (0.015 to 0.223$)$ & 0.025 \\
\hline Dist. home-work\# & $-0.244(-0.447$ to -0.041$)$ & 0.019 & $0.031(-0.225$ to 0.288$)$ & 0.81 & $-0.066(-0.427$ to 0.295$)$ & 0.718 & $-0.033(-0.145$ to 0.08$)$ & 0.572 \\
\hline Time $t_{0}$ to $t_{1}$ & $0(-0.001$ to 0$)$ & 0.299 & 0.001 (0 to 0.002 ) & 0.157 & $0.001(-0.001$ to 0.002$)$ & 0.442 & $0(0$ to 0.001$)$ & 0.65 \\
\hline
\end{tabular}

\# Built environment and PT accessibility variables were standardized (with mean $=0$ and $S D=1$ ). 


\section{Supplementary References}

ACEA/ANFAC (2014) European Motor Vehicle Parc 2014: Vehicles in Use (2009-2014). ANFAC/ACEA, Madrid.

DEFRA/DECC, (2016) UK Government conversion factors for Company Reporting, full 2016 dataset. Department for the Environment, Food and Rural Affairs and Department for Energy and Climate Change, London.

DfT, (2015) Transport Statistics Great Britain: 2015 Edition. Department for Transport, London.

EC DG Climate Action (2013) Transport database TRACCS (Transport data collection supporting the quantitative analysis of measures relating to transport and climate change). Emisia, Infras and IVL for the European Commission, Brussels.

EEA, (2012) COPERT 4 (COmputer Programme to calculate Emissions from Road Transport), last accessed at http://emisia.com/content/copert-documentation on 20/02/2018. European Environment Agency, Copenhagen.

EMEP/EEA, (2016) EMEP/EEA air pollutant emission inventory guidebook 2016, Technical guidance to prepare national emission inventories. European Environment Agency, Copenhagen.

Eurostat (2016) Transport data database, October 2015 update. Last accessed at http://ec.europa.eu/eurostat/web/transport/data/database on 10/03/2017. Eurostat, European Commission, Brussels.

IEA (2015) World energy outlook 2015. International Energy Agency (IEA), Paris.

IIASA, (2014) IIASA GAINS model, scenario WPE_2014_CLE: the updated 'current legislation' (after the bilateral consultations in 2014) of the PRIMES 2013 REFERENCE activity projection. IIASA, Laxenburg, Austria.

Odeh, N., Hill, N., Forster, D. (2013) Current and Future Lifecycle Emissions of Key „Low Carbon" Technologies and Alternatives, Final Report. Ricardo AEA for the Committee on Climate Change, Harwell, UK.

SMMT (2014) New Car $\mathrm{CO}_{2}$ Report 2014: The 13th report. The Society of Motor Manufacturers and Traders (SMMT), London.

SMMT, (2016) UK new car market starts 2016 on a high with best January in 11 years, http://www.smmt.co.uk/2016/02/uk-new-car-market-starts-2016-on-a-high-with-best-january-in11-years/ [last accessed on 18/01/2016]. SMMT, London. 